\title{
Extraction of Some Ellagic Tannins and Ellagic Acid from Oak Wood Chips (Quercus pyrenaica L.) in Model Wine Solutions: Effect of Time, pH, Temperature and Alcoholic Content
}

\author{
A.M. Jordão, J.M. Ricardo-da-Silva* and O. Laureano \\ Universidade Técnica de Lisboa, Instituto Superior de Agronomia, Laboratório Ferreira Lapa (Sector de Enologia), 1349-017 Lisboa, \\ Portugal. Fax. ++351.213653200; telef. ++351.213653542
}

Submitted for publication: October 2004

Accepted for publication: September 2005

Key words: alcoholic content, ellagic tannins, ellagic acid, oak wood, $\mathrm{pH}$, temperature, time

\begin{abstract}
The subject of the present work is the study of the influence of $\mathrm{pH}$, temperature, alcoholic content and time on the extraction of some individual ellagic tannins (castalagin, vescalagin, grandinin, roburin D and E) and ellagic acid from oak wood chips (Quercus pyrenaica $\mathrm{L}$.) within model wine solutions. The determination of these compounds by reversed-phase high-performance liquid chromatography (HPLC), after 104 extraction days, enabled us to establish the qualitative and quantitative evolution of each component and the effect of each extraction condition on individual and total ellagic tannins from oak wood chips. Vescalagin and castalagin were the most abundant individual ellagic tannins measured under all extraction conditions. Individual ellagic tannins and ellagic acid increased during the first weeks of extraction, followed by a decrease. Under the extraction conditions examined, temperature was the main factor influencing ellagic tannins and elagic acid evolution. The results suggest that a decrease/degradation of these compounds is less noticeable at low temperatures $\left(12^{\circ} \mathrm{C}\right)$. After 104 extraction days the ellagic tannins content in a model wine solution at $12^{\circ} \mathrm{C}$ was higher than the content of ellagic tannins in solutions at $20^{\circ} \mathrm{C}$. On the other hand, the effects of alcoholic content and $\mathrm{pH}$ of model wine solutions on the extraction and evolution of the analysed compounds (except for castalagin and vescalagin) seemed to be less important than temperature.
\end{abstract}

For many centuries oak wood has traditionally been used in the storage of alcoholic beverages because of its mechanical properties (hardness, pliability and impermeability) and its extractable compounds, which can produce changes in the composition of wines and spirits. The oak wood species most commonly used in barrel-making are Quercus alba (grown mainly in the United States), Quercus petraea and Quercus robur (grown in Europe and Eastern Europe). In Portugal, the most commonly used oak wood species is Quercus pyrenaica, and it is traditionally used in barrel-making.

During the aging of spirits and wines in barrels, various components of the wood diffuse into the liquid, improving the organoleptic quality. These components include tannins (Peng et al., 1991; Viriot et al., 1993; Vivas et al., 1996), lignin derivates (Puech et al., 1996), and volatile constituents (Chatonnet et al., 1997; Chatonnet \& Dubourdieu, 1998; Chatonnet, 1999).

Chen (1970) and Seikel et al. (1971) detected the presence of ellagic tannins in oak wood. These compounds are present in numerous species of oak (Quercus sp.). They belong to the group of hydrolysable tannins (Haslam, 1981) and can represent up to $10 \%$ of the dry material (Scalbert et al., 1988). The two most common ellagic tannins have been isolated and identified as vescalagin and castalagin by Mayer (1971). Subsequently, six additional water-soluble ellagic tannins (roburins A-E and gran- dinin) were also acknowledged (Du Penhoat et al., 1991) as dimers of vescalagin or castalagin and/or characterised by the addition of a pentose residue to said molecules. Castalin and vescalin are further present in oak wood and have been classified as ellagic tannins by Mayer et al. (1967) even though they do not liberate ellagic acid on acid hydrolysis.

The above-mentioned ellagic tannins are water soluble and soluble in hydroalcoholic solutions such as wines and spirits (Moutounet et al., 1989; Viriot et al., 1993). Their taste properties (Pocock et al., 1994) grant them an important role in the aging process of red wines (Singleton, 1995; Vivas \& Glories, 1996) and spirits in oak barrels (Puech, 1987; Viriot et al., 1993).

Many authors suggest that ellagic tannins may be involved in red and white wine oxidation processes (Pontallier et al., 1982; Moutounet et al., 1989). Moutounet et al. (1993) confirmed this after studying the behaviour of a dry white wine supplemented with ellagic tannins, the presence of which increased the oxygen consumption rate (compared to the control wine). Recently, Vivas \& Glories (1996) showed that ellagic tannins play an important role in wine oxidation processes, quickly absorbing the dissolved oxygen and facilitating the hydroperoxidation of wine constituents. Pursuant Vivas \& Glories (1993), oak wood ellagic tannins also affect the proanthocyanidins condensation rate, as well as condensed tannin precipitation and anthocyanidin destruction.

\footnotetext{
*Corresponding author: E-mail address: jricardosil@isa.utl.pt

Acknowledgements: The authors would like to thank the company Tanoaria J.M. Gonçalves Lda (Palaçoulo, Portugal) for supplying the oak wood chips. The Portuguese Science Ministry (Project POCTI/AGR/36168/2000) sponsored this study.
} 
Combination with wine polysaccharides and proteins during wine ageing, particularly with batonnage, is another role of the ellagic tannins (Dubourdieu, 1992). As a consequence of these reactions, the concentration of ellagic tannins in wines that are cask matured is low (Quinn \& Singleton, 1985; Moutounet et al., 1989). According to Moutounet et al. (1989), the ellagic tannins are rapidly extracted from oak chips by a $12 \%$ hydroalcholic solution, with the maximum extraction of $4 \mathrm{~g} / \mathrm{L}$ chips obtained after eight hours of contact under agitation. As a consequence of the lower stability of the majority of these compounds after the ellagic tannin extraction, some authors reported a decline in concentration of these compounds (Moutounet et al., 1993). Some studies suggest that the disappearance of ellagic tannins coincides with the addition of ethoxy moieties and leads to the formation of hemiketal and ketal ellagic tannins (Moutounet et al., 1992; Puech et al., 1999). On the other hand, Mertz (1996) confirmed the lower stability of some individual ellagic tannins (vescalagin and castalagin) in model solutions at different temperatures.

In general, studies have emphasised the composition of extractable ellagic tannins from different oak wood species using model wine solutions or different organic solvents. The roles of the wine maturation environment, and the physical and chemical composition of hydroalcoholic solutions used for ellagic tannin extraction have rarely been considered in enology studies. Consideration of this is very important because there are many factors present during wine aging in oak wood casks that could perhaps affect the extraction of individual ellagic tannins from oak wood or their evolution during the aging process. On the other hand, the composition of ellagic tannins of oak species grown in Portugal (Quercus pyrenaica), and traditionally used in Portuguese cooperage, has not yet been investigated. Recently, Canas et al. (2000) only studied the ellagic acid content. They found that Portuguese oak has a higher content of ellagic acid than the French and American oak species used.

Therefore, the aim of this study was to examine the variation in concentration of some individual ellagic tannins and ellagic acid extracted from a much less studied oak wood species (Quercus pyrenaica L.) using wood chips in model wine solutions, and to determine the relative influence of temperature, alcoholic content, $\mathrm{pH}$ and time on their contents. The conditions/values used in this study were generally similar to those used in enology. This aspect is of considerable interest for coopers and especially for winemakers to enable them to choose wisely the best wine aging conditions for the best wine characteristics.

\section{MATERIALS AND METHODS}

\section{Samples}

The samples used in this study were oak wood chips ( 0.5 to 5 $\mathrm{mm}$ ) from Quercus pyrenaica L. (Gerês forest, North of Portugal), with medium toasting intensity (35 min) and grain (growth rings, $3.5 \mathrm{~mm}$ ), which were supplied by J.M. Gonçalves Lda company (Palaçoulo, North of Portugal).

\section{Extraction under model wine conditions}

In order to study the effect of $\mathrm{pH}$, temperature, alcoholic content and time on the extraction/evolution of the quantitatively most important individual ellagic tannins (vescalagin, castalagin, roburin $\mathrm{D}$, roburin $\mathrm{E}$ and grandinin) and ellagic acid from oak wood chips, the wood chips samples $(3 \mathrm{~g} / \mathrm{L}$ ) were placed in 250
$\mathrm{mL}$ of the different model wine solutions for 104 days $(280 \mathrm{~mL}$ was the total volume of the bottles containing the model wine solutions). The samples, prepared in duplicate, were subjected to different extraction conditions (similar to conditions that usually occur during wine aging) in the dark and were agitated daily (under magnetic stirring for 5 min each day).

Thus the different extraction conditions studied for model wine solutions were: $p H$ assay - pH 3.1 and 3.7, both for an alcoholic degree of $12 \%(\mathrm{v} / \mathrm{v})$ and at a temperature of $20^{\circ} \mathrm{C}$; alcoholic degree assay - alcoholic degree of 10 and $13 \%(\mathrm{v} / \mathrm{v})$, both at $\mathrm{pH}$ 3.1 and a temperature of $20^{\circ} \mathrm{C}$; temperature assay - temperature of 12 and $20^{\circ} \mathrm{C}$, both at $\mathrm{pH} 3.1$ and an alcoholic degree of $12 \%$ $(\mathrm{v} / \mathrm{v})$. All extraction assays were done in duplicate.

For each analysis of individual ellagic tannins extracted from oak wood chips, $2 \mathrm{~mL}$ of the maceration liquid from each wine model solution was filtered through a Millipore filtration membrane (pore diameter, $0.45 \mu \mathrm{m}$ ). The resulting filtrate was concentrated under a nitrogen stream so as to eliminate water and oxygen, and its volume made up to $3 \mathrm{~mL}$ with water. Afterwards, $10 \mu \mathrm{l}$ aliquots were analysed by high-pressure liquid chromatography (HPLC), in duplicate, using the method described by Viriot et al. (1994). Ellagic acid was directly evaluated from the filtrate and injected, in duplicate, into the HPLC column.

\section{Ellagic tannins and ellagic acid analysis}

The equipment used for analytical HPLC was a Konic 500B system (Konik Instruments, Spain) with a 7161-LC Rheodyne valve. Detection was made at $280 \mathrm{~nm}$, for ellagic tannins, and at $370 \mathrm{~nm}$ for ellagic acid with a Konik UV-Vis detector model 206 PHD, coupled to a Konikron data treatment system. The column $(250 \times$ $4.6 \mathrm{~mm}$, with a particle size $5 \mu \mathrm{m}$ ) was a reverse-phase ${ }^{C_{18}}$ LiChrospher $^{\circledR} 100$ (Merck, Darmstadt) protected by a guard column of the same material.

As regards the ellagic tannins' determination, a linear gradient was used with the following elution conditions: solvent A (water/phosphoric acid 990:1, v:v) and solvent B (methanol); gradient, 0 to $10 \% \mathrm{~B}$ in 30 minutes, and flow rate, $1 \mathrm{~mL} /$ minute. Another linear gradient was used for the ellagic acid determination, with the following elution conditions, and using the same solvents: gradient, 0 to $90 \% \mathrm{~B}$ in $30 \mathrm{~min}$, and flow rate, 1 $\mathrm{mL} / \mathrm{min}$. The column was washed between injections with methanol/water (500:500, v/v) for $15 \mathrm{~min}$. All analyses were done in duplicate. The chromatographic peaks of ellagic tannins were identified according to reference data previously described (Viriot et al., 1994), and for ellagic acid the identification of a chromatographic peak was made by comparison of its retention time with that of an external standard. The results of individual ellagic tannins are expressed in $\mathrm{mg} / \mathrm{L}$ ellagic acid (Fluka) equivalents. The compounds corresponding to the five ellagic tannins and ellagic acid observed by reversed-phase HPLC are shown in Fig. 1. Roburins A, B and C were not individually identified and quantified in this work, but it was possible to detect them as a broad peak in the HPLC chromatogram.

\section{Data analysis}

In order to study the influence of the various factors on the extraction of individual ellagic tannins and ellagic acid from oak wood, an analysis of variance and comparison of treatment means (ANOVA, one-way) was performed using the SPSS software pro- 


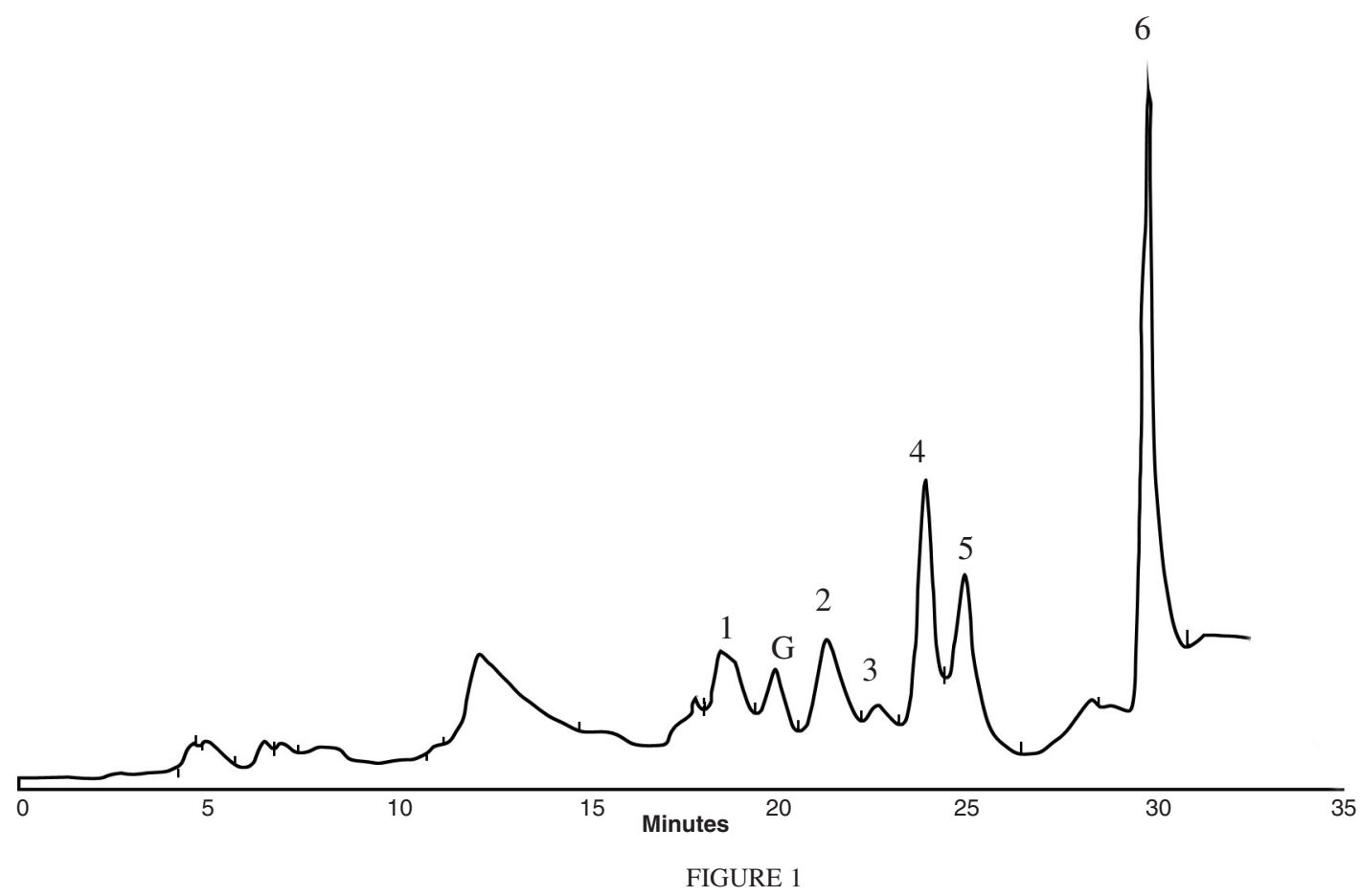

Reverse-phase HPLC chromatogram of ellagic tannins from oak wood chip extract.

Peak assignments: 1, roburins A, B and C; 2, grandinin; 3, roburin D; 4, vescalagin; 5, roburin E; 6, castalagin. G, gallic acid.

gram version 11.0 (SPSS Inc. Headquarters, Chicago, Illinois, USA) for total and each individual ellagic tannins and ellagic acid.

\section{RESULTS AND DISCUSSION}

\section{Kinetics of ellagic tannins and ellagic acid extraction as func- tion of time}

The evolution of the concentration of the total and individual ellagic tannins in the studied model wine solutions is shown in Figs 2 to 5. Assessment of the latter figure led us to conclude that there were two distinct stages during the extraction process (under all extraction conditions). An initial period (in general, between 16 and 40 extraction days), during which supply of ellagic tannins and ellagic acid to the oak wood chips/model wine solutions contact layer was high, due to the solubility of the compounds, and a second period during which there was a clear, continuous decrease in their values.

The proportion of ellagic tannins extracted from the oak wood chips varied significantly amongst individual tannins. In general, the results indicated that, under all extraction conditions, after one extraction day, ellagic tannins and ellagic acid were already present in the model wine solutions. It should be noted that in the assay where the influence of temperature on the extraction process was studied, after only one day we registered a total value of approximately $50 \mathrm{mg} / \mathrm{L}$ (expressed in ellagic acid equivalent) in all compounds studied (see Fig. 2).

In respect of roburin $\mathrm{D}$, only after 8 and 16 extraction days was it possible to observe this compound in the model wine solutions (see Figs 3 to 5). These results suggest that both molecules of roburin are less accessible or extractable than other ellagic tannins when an aqueous ethanol solution is used. This compound may be more closely associated with the cell wall components and therefore less easily extracted into solution. On the other
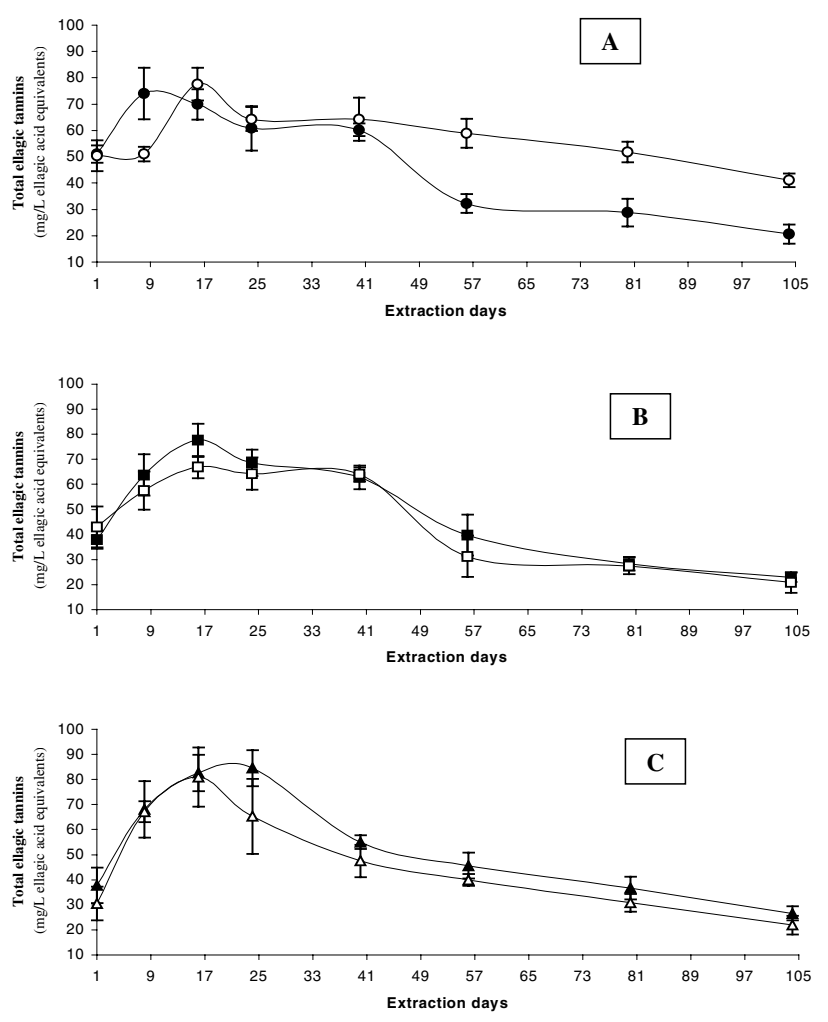

FIGURE 2

Evolution of total ellagic tannins quantified during 104 extraction days in model wine solutions under different extraction conditions (for extraction conditions see material and methods).

A - Influence of temperature: - - temperature $20^{\circ} \mathrm{C}$; - $\mathrm{O}$ - temperature $12^{\circ} \mathrm{C}$ $\mathrm{B}$ - Influence of $\mathrm{pH}$ conditions: $-\square-\mathrm{pH}=3.7 ;-\square-\mathrm{pH}=3.1$

$\mathrm{C}$ - Influence of alcoholic degree: - $\boldsymbol{\Lambda}$ - alcoholic degree $13 \%(\mathrm{v} / \mathrm{v})$; $-\triangle$ - alcoholic degree $10 \%(\mathrm{v} / \mathrm{v})$ 

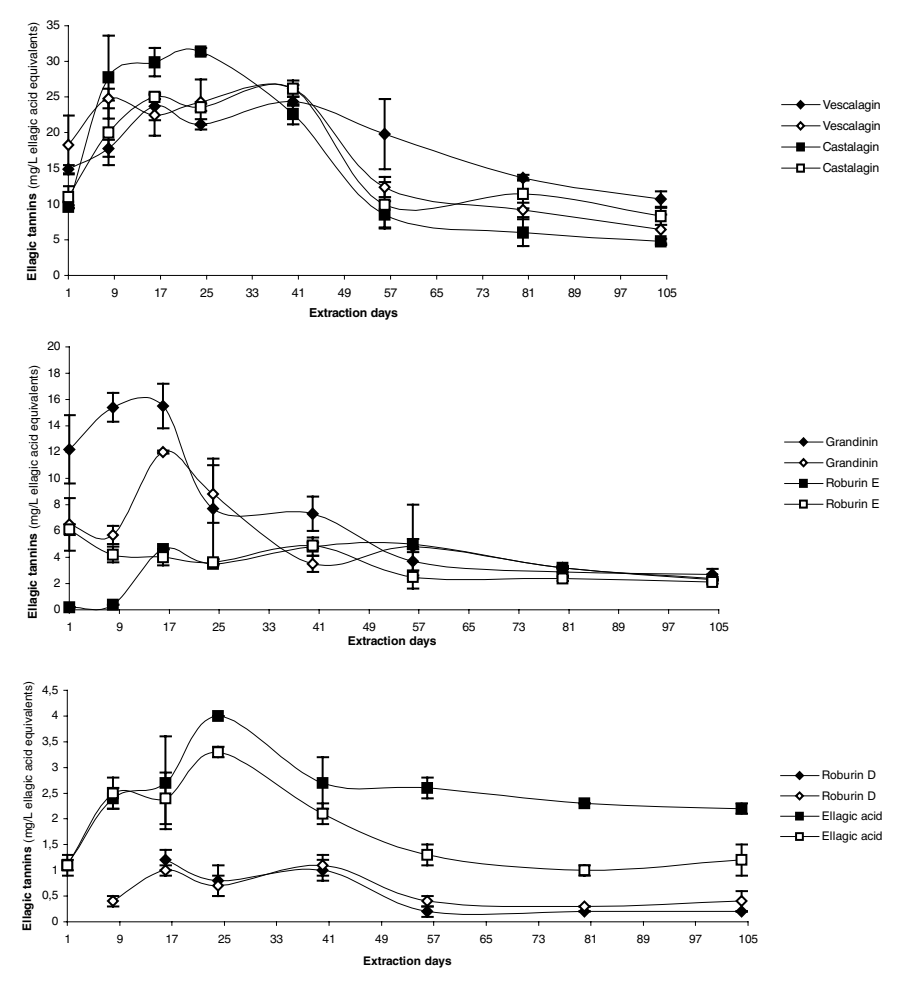

FIGURE 3

Evolution of individual ellagic tannins and ellagic acid quantified during 104 extraction days in model wine solutions under different $\mathrm{pH}$ conditions

$(-\diamond-,-\mathbf{p H}=3.7 ;-\diamond-,-\square-\mathrm{pH}=3.1)$.
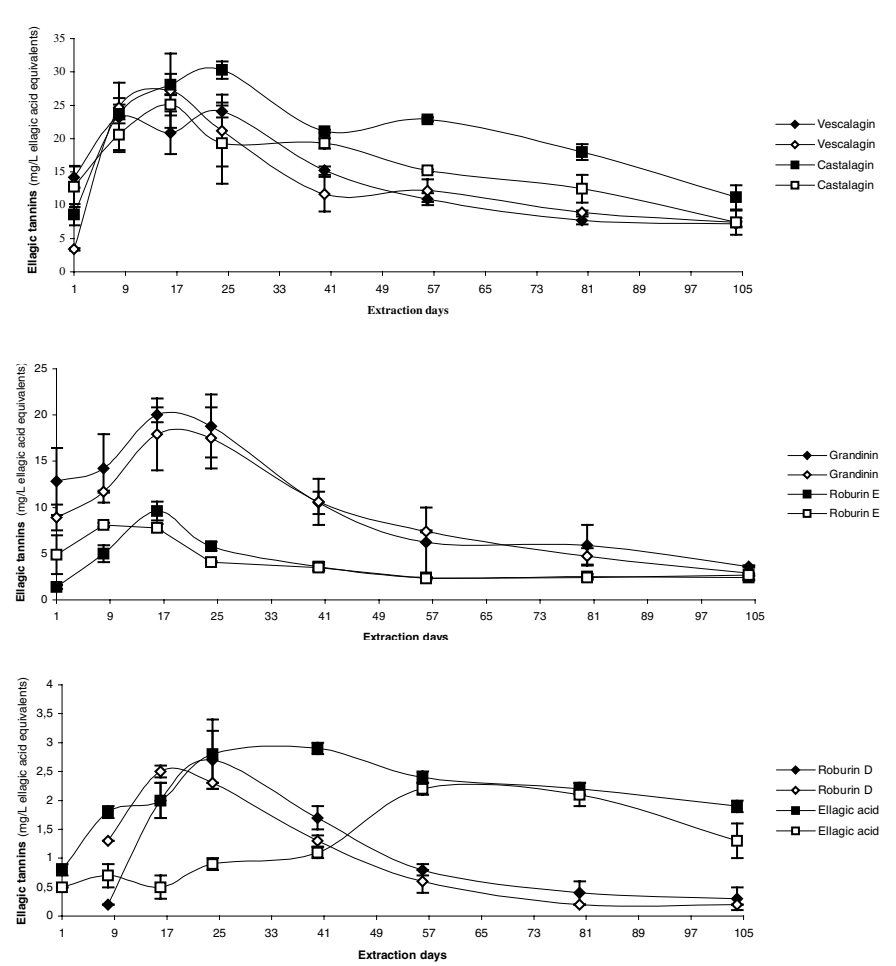

FIGURE 4

Evolution of individual ellagic tannins and ellagic acid quantified during 104 extraction days in model wine solutions under different alcoholic degree conditions $(-\bullet-,-13 \% \mathrm{v} / \mathrm{v} ;-\diamond-,-\square-10 \% \mathrm{v} / \mathrm{v})$.
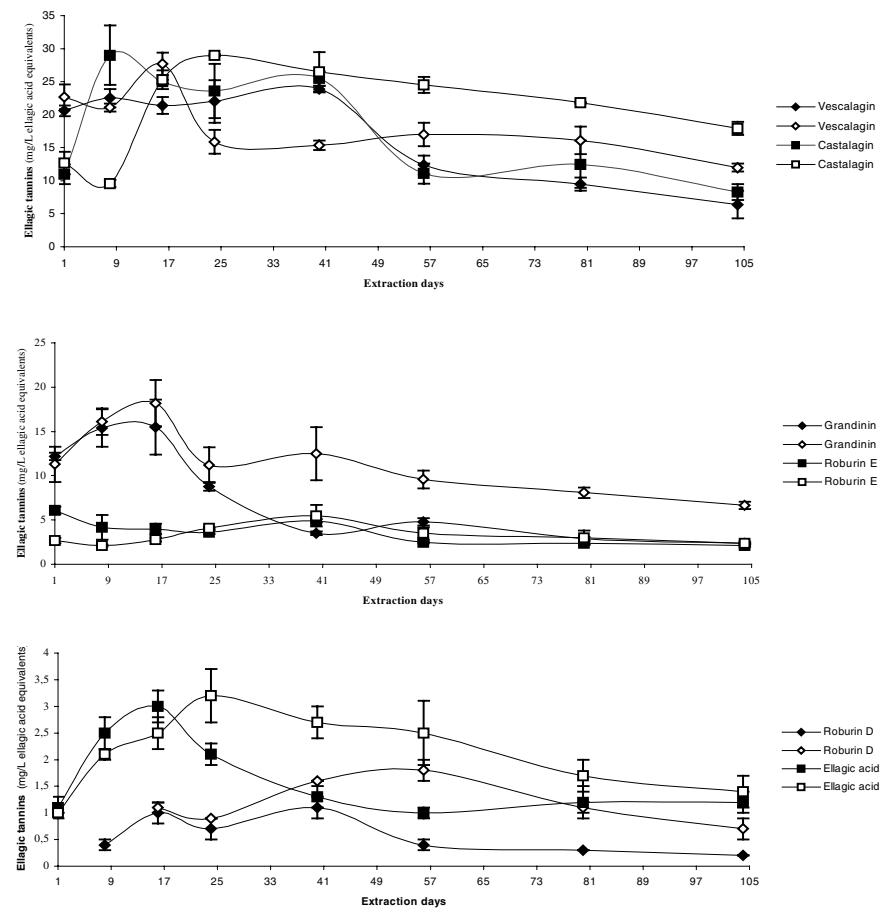

FIGURE 5

Evolution of individual ellagic tannins and ellagic acid quantified during 104 extraction days in model wine solutions under different temperature conditions $\left(-\diamond-,-\square-; 20^{\circ} \mathrm{C},-\diamond-,-\square-12^{\circ} \mathrm{C}\right)$.

hand, roburin D is usually the minor ellagic tannin quantified in oak wood. However, a recent study on the extraction of ellagic tannins from oak wood (Quercus robur) of model casks showed that castalagin and vescalagin are less accessible or extractable than other ellagic tannins (Puech et al., 1996). Masson et al. (1994) found that while the concentration of ellagic tannins varied between different wood tissues, the composition remained relatively constant.

While roburin D was the ellagic tannin extracted from oak wood chips in lesser quantities, castalagin, vescalagin and grandinin were the dominant ellagic tannins under all extraction conditions assayed. For example, in the assay in which the effect of alcoholic degree was assessed (Fig. 4), vescalagin and castalagin showed, a 27.2 and $28.1 \mathrm{mg} / \mathrm{L}$ concentration (ellagic acid equivalent), respectively, after 16 days of extraction, while in the same assay roburin D displayed a value of only $2.0 \mathrm{mg} / \mathrm{L}$ (ellagic acid equivalent). Grandinin was another important ellagic tannin extracted in all assays. After 104 extraction days the values that were determined varied from 2.4 to $6.6 \mathrm{mg} / \mathrm{L}$ (ellagic acid equivalent). These results confirm the trends found in other studies in which other extraction methods, oak wood species (include Quercus pyrenaica specie) or green untoasted and toasted wood, were used (Viriot et al., 1994; Vivas \& Glories, 1996; Puech et al., 1996; Feuillat et al., 1997; Fernandez de Simon et al., 1998; Matricardi \& Waterhouse, 1999; Cadahía et al., 2001). Feuillat et al. (1997), using ethanol solutions (12\% v/v) in model casks (Quercus robur and Quercus petraea), reported high values of vescalagin and castalagin after 200 days of extraction, under cel- 
lar conditions. Thus, vescalagin values ranged from 6.1 to 39.9 $\mathrm{mg} / \mathrm{L}$ and for castalagin the values varied from 9.7 to $45.6 \mathrm{mg} / \mathrm{L}$.

In general, after between 16 and 40 extraction days, we observed an evident decrease of the compounds under all extraction conditions (see Figs 2 to 5). Presumably this decrease is a consequence of their participation in oxidation reactions (using the oxygen dissolved in the solutions), causing them to degrade and consequently leading to a decrease in their values. However, in all the chromatograms that were recorded it was not possible to detect new or 'additional' chromatographic peaks as a consequence of the degradation of the ellagic tannins. Only a decrease in the values of each compound studied was observed. It is possible that other/new products may be detected using another HPLC method and/or at another wavelength.

Thus, this possible additional reaction explains the weak concentrations of ellagic tannins found after 104 extraction days. This result is consistent with the observation reported by Moutounet et al. (1992), according to which after extraction of ellagic tannins additional reactions may probably occur, that may result in a transformation/degradation of these compounds and in a decrease in their values. Moutounet et al. (1992) and Singleton (1995) suggested that ellagic tannin might be more stable in real wine than in an ethanol solution, as other wine components may oxidise more readily than the ellagic tannins. According to Vivas \& Glories (1996), these results may be explained by the fact that during the wine aging process the ellagic tannins have faster and easier oxidation ability than other wine constituents.

Some authors (Vivas \& Glories, 1996; Vivas et al., 1996) considered that the large capacity for ellagic tannins to consume oxygen is due to the presence of several hydroxy functions in the ortho position, which induce an increase in the reducing power of the ellagic tannins.

\section{Effect of pH, temperature and alcoholic content on the extraction/evolution of ellagic tannins and ellagic acid}

Figures 2 and 3 show the influence of $\mathrm{pH}$ (of similar values to those found in wines) on the extraction/evolution of ellagic tannins and ellagic acid in model wine solutions. For the total ellagic tannins quantified during 104 extraction days the evaluation of the values showed that the increase in $\mathrm{pH}$ values (from $\mathrm{pH} 3.1$ to $\mathrm{pH}$ 3.7) did not have any effect on the evolution/extraction of the compounds (see Fig. 2). On the other hand, for the individual compounds analysed, the results suggest that the increase in $\mathrm{pH}$ values had a slight positive effect on the extraction only for some ellagic tannins (grandinin and castalagin) and ellagic acid (see Fig. 3). Thus, for example, in the case of grandinin, after 1 extraction day, this compound was found in concentrations of 12.2 $\mathrm{mg} / \mathrm{L}$ and $6.5 \mathrm{mg} / \mathrm{L}$ (ellagic acid equivalents) at $\mathrm{pH} 3.7$ and $\mathrm{pH}$ 3.1 , respectively.

A similar effect was observed with reference to castalagin and ellagic acid. After 24 extraction days, castalagin was found in concentrations of $31.4 \mathrm{mg} / \mathrm{L}$ and $23.6 \mathrm{mg} / \mathrm{L}$ (ellagic acid equivalents) at pH 3.7 and pH 3.1, respectively. However, it is worth noting that after 104 extraction days the total ellagic tannins extracted under each of the $\mathrm{pH}$ conditions assayed did not show a significant difference (see Table 1). On the other hand, the analysis of variance and comparison of means for individual ellagic tannins quantified in $\mathrm{pH}$ assays after 104 days showed that only for vescalagin and castalagin were the values significantly different. For vescalagin the mean value was higher in solution at $\mathrm{pH} 3.7$ (10.7 mg/L ellagic acid equivalents) than at $\mathrm{pH} 3.1(6.4 \mathrm{mg} / \mathrm{L}$ ellagic acid equivalents), and for castalagin the mean value was 8.3 and $4.8 \mathrm{mg} / \mathrm{L}$ ellagic acid equivalents at $\mathrm{pH} 3.1$ and 3.7, respectively.

The results obtained in our study concerning the influence of $\mathrm{pH}$ on castalagin and ellagic acid extraction using model wine solutions are in accordance with the findings of previous studies reported by Peng et al. (1991). They found that the extractability of tannins by water could be significantly improved by increasing the $\mathrm{pH}$. In addition, as regards roburins $\mathrm{D}$ and $\mathrm{E}$, the $\mathrm{pH}$ value did not seem to affect the extraction process.

The influence of the alcoholic degree of model wine solutions on the total and individual ellagic tannin extractions is presented in Figs 2 and 4, respectively. In general, results show that the alcoholic degree did not influence the extraction of the compounds under study, both individually as well as in terms of total values, during the 104 days of extraction. Vivas et al. (1996) also found that the values of ellagic tannins extracted from wood samples, using a hydroalcoholic solution with a composition similar to that of the wine, were comparable to values recorded for water extractions. Thus, these results suggest that the alcoholic degree normally reached in wines cannot be an important factor for ellagic tannin extraction/degradation during wine oak aging. Conceivably, in the case of spirits, where alcoholic degree values are much higher, this factor can be decisive and, therefore, results can be different.

In relation to the effect of temperature, the total ellagic tannins extracted from the oak wood chips were quite similar at both tem-

\section{TABLE 1}

Influence of the temperature, alcoholic degree and $\mathrm{pH}$ conditions on ellagic tannins (expressed in $\mathrm{mg} / \mathrm{L}$ ellagic acid equivalents) and ellagic acid (mg/L) mean values after 104 extraction days from oak wood chips (Quercus pyrenaica L.) in model wine solutions.

\begin{tabular}{|c|c|c|c|c|c|c|}
\hline \multirow[b]{3}{*}{ Compounds } & \multicolumn{6}{|c|}{ Extraction conditions } \\
\hline & \multicolumn{2}{|c|}{$\begin{array}{c}\text { Temperature } \\
\text { assay }\end{array}$} & \multicolumn{2}{|c|}{$\begin{array}{l}\text { Alcoholic degree } \\
\text { assay }^{2}\end{array}$} & \multicolumn{2}{|c|}{$\underset{\text { assay }^{3}}{\text { pH }}$} \\
\hline & T12 & T20 & AD10 & AD13 & pH3.1 & pH3.7 \\
\hline Vescalagin & $12.0^{\mathrm{A}}$ & $6.4^{\mathrm{B}}$ & $7.4^{\mathrm{B}}$ & $7.2^{\mathrm{B}}$ & $6.4^{\mathrm{B}}$ & $10.7^{\mathrm{A}}$ \\
\hline Castalagin & $17.9^{\mathrm{A}}$ & $8.3^{\mathrm{B}}$ & $7.4^{\mathrm{B}}$ & $11.2^{\mathrm{B}}$ & $8.3^{\mathrm{B}}$ & $4.8^{\mathrm{C}}$ \\
\hline Grandinin & $6.6^{\mathrm{A}}$ & $2.4^{\mathrm{B}}$ & $2.4^{\mathrm{B}}$ & $3.6^{\mathrm{B}}$ & $2.4^{\mathrm{D}}$ & $2.7^{\mathrm{D}}$ \\
\hline Roburin D & $0.7^{\mathrm{A}}$ & $0.2^{\mathrm{A}}$ & $0.2^{\mathrm{A}}$ & $0.3^{\mathrm{A}}$ & $0.4^{\mathrm{D}}$ & $0.2^{\mathrm{D}}$ \\
\hline Roburin E & $2.4^{\mathrm{A}}$ & $2.1^{\mathrm{A}}$ & $2.7^{\mathrm{A}}$ & $2,4^{\mathrm{A}}$ & $2.1^{\mathrm{D}}$ & $2.3^{\mathrm{D}}$ \\
\hline Ellagic acid & $1.4^{\mathrm{A}}$ & $1.2^{\mathrm{A}}$ & $1.3^{\mathrm{A}}$ & $1.9^{\mathrm{A}}$ & $1.2^{\mathrm{D}}$ & $2.2^{\mathrm{A}}$ \\
\hline Total & $41.0^{A}$ & $20.6^{\mathrm{B}}$ & $21.4^{B}$ & $26.6^{B}$ & $20.8^{B}$ & $22.9^{B}$ \\
\hline
\end{tabular}

${ }^{1}$ Temperature assay conditions: $\mathrm{T} 12=12^{\circ} \mathrm{C} ; \mathrm{T} 20=20^{\circ} \mathrm{C}$.

${ }^{2}$ Alcoholic degree assay conditions: $\mathrm{AD} 10=10 \%(\mathrm{v} / \mathrm{v}) ; \mathrm{AD} 13=13 \%(\mathrm{v} / \mathrm{v})$.

${ }^{3} \mathrm{pH}$ assay conditions: $\mathrm{pH} 3.1=3.1 ; \mathrm{pH} 3.7=3.7$.

${ }^{4}$ Analysis of variance and comparison of treatment means (ANOVA). Means followed by the same letter are not significantly different $(\mathrm{p}<0.05)$.

${ }^{5}$ Each value represents the mean from duplicate samples. 
peratures studied $\left(12\right.$ and $\left.20^{\circ} \mathrm{C}\right)$, during the first 40 extraction days, followed by a decrease that was more evident in the model wine solution at $20^{\circ} \mathrm{C}$ (see Fig. 2).

Studies of the extraction from oak wood chips using white wine were carried out at both $13^{\circ} \mathrm{C}$ and $25^{\circ} \mathrm{C}$. At the higher temperature, 2.18 times more vescalagin and castalagin was extracted, compared with between 1.33 and 1.73 times, as regards other ellagic tannins (Puech et al., 1994). On the other hand, Peng et al. (1991) reported that the extractability of tannins could be improved significantly by raising the temperature to $100^{\circ} \mathrm{C}$. In fact, temperature is an important factor influencing the extractability of these compounds from oak wood, although differences may be more noteworthy when using much higher temperature variations.

Thus, the temperature used in our experiments did not affect the ellagic tannins extraction process. In general, the results suggest that the decrease/degradation observed for the total ellagic tannins in the last maceration weeks (since 40 extraction days) was less considerable when hydroalcoholic solutions, containing oak wood samples, were at a temperature of $12^{\circ} \mathrm{C}$ (temperature close to the cellar conditions of wine aging). The values obtained for the total compounds extracted indicate that differences between temperatures were more substantial from the $56^{\text {th }}$ extraction day until the $104^{\text {th }}$ day (see Fig. 2). Hence, this result demonstrates that temperature may play an important role in the degradation of ellagic tannins and ellagic acid during that time, given that at a $12^{\circ} \mathrm{C}$ temperature the decrease in ellagic tannins was less evident. For vescalagin, castalagin and grandinin the mean values were significantly different (see Table 1). For example, after 104 extraction days, $12 \mathrm{mg} / \mathrm{L}$ (ellagic acid equivalents) of vescalagin was quantified at $12^{\circ} \mathrm{C}$, whereas after the same extraction time at $20^{\circ} \mathrm{C}$ the mean value was $6.4 \mathrm{mg} / \mathrm{L}$ (expressed in ellagic acid equivalents). Significantly different values were recorded for total compounds extracted after 104 days $\left(20.6 \mathrm{mg} / \mathrm{L}\right.$ and $41.0 \mathrm{mg} / \mathrm{L}$ at $20^{\circ} \mathrm{C}$ and $12^{\circ} \mathrm{C}$, respectively). The results reported emphasise the influence of temperature in ellagic tannin stability under model wine conditions. Another study (Mertz, 1996) had in fact confirmed the lower stability of vescalagin in model solutions at different temperatures, as a consequence of a higher susceptibility to oxidation in alcoholic solutions than castalagin is. In another study, Vivas et al. (1995) confirmed that vescalagin has more polar configuration than castalagin, as well as a much greater largely hydrophilic zone and a different electrostatic potential. These factors may explain why vescalagin is more susceptible to oxidation in alcoholic solution than castalagin is (Vivas, 1997). However, it is important to note that the results obtained in our study did not confirm that vescalagin has a greater susceptibility to oxidation than castalagin has at different temperatures. Further experiments will be necessary to determine the susceptibility of each of the individual ellagic tannins to oxidation at different temperatures.

\section{CONCLUSIONS}

In all extraction conditions studied, the evolution of ellagic tannins and ellagic acid extracted from oak wood chips (Quercus pyrenaica L.) in model wine solutions displayed an increase in the first 40 extraction days, which was followed by a gradual decrease. This evolution suggests that significant degradation of ellagic tannins and ellagic acid occurs after their extraction into solution. The role of oxidation, polymerisation or hydrolysis reactions may explain the lower levels of ellagic tannins present in solutions after long periods of extraction. However, in the chromatograms no 'additional' or new chromatographic peaks (due polymers) were observed (under the HPLC conditions used in this study) as a consequence of ellagic tannin degradation. On the other hand, perhaps the ellagic tannin degradation (namely hydrolysis) lead to the formation of ellagic acid in the model wine solutions, but in our work the levels of ellagic acid compound did not increase during the extraction process. This situation can rather be explained as a consequence of the oxygen level in the solutions that determines the total ellagic acid oxidation (ellagic acid from oak wood chips and from ellagic tannin degradation). Another possibility is that the ellagic tannins, in their native form, undergo such rapid transformations that they do not hydrolyse to form ellagic acid.

On the other hand, our study was carried out with heated wood and it is therefore essential to account for the effects of the heating process. This could therefore explain the varying permeability of wood in ethanol solutions and maybe the solubility of the ellagic tannins.

Of the several wine-aging conditions studied, only temperature had a significant effect on the ellagic tannins content in the model wine solutions. Thus, in general, the temperature used during wine aging (close to $12^{\circ} \mathrm{C}$ ) appears to have less of an influence on ellagic tannins degradation, probably due to the regulation of oxidative reactions. Vescalagin and castalagin were the most abundant individual ellagic tannin compounds measured, followed by grandinin and roburin $\mathrm{E}$, while roburin $\mathrm{D}$ was the ellagic tannin least detected in all extraction processes.

Further experiments will be necessary to determine the influence of the oxygen level in the model solution, the activity of micro-organism in oak wood chips and the $\mathrm{SO}_{2}$ levels in the solution in order to help to establish the best environment conditions (similar to wine aging) for ellagic tannin extraction and the maintenance of their values during the wine aging.

\section{LITERATURE CITED}

Cadahía, E., Varea, S., Muñoz, L., Fernández de Simón, B. \& García-Vallejo, M.C. 2001. Evolution of ellagic tannins in Spanish, French, and American oak woods during natural seasoning and toasting. J. Agric. Food Chem. 49, 3677-3684.

Canas, S., Leandro, M.C., Spranger, M.I. \& Belchior, A.P., 2000. Influence of botanical species and geographical origin on the content of low molecular weight phenolic compounds of wood used in Portuguese cooperage. Holzforschung 3 , 225-261.

Chatonnet, P., Ricardo-da-Silva, J.M. \& Dubourdieu, D., 1997. Influence de l'utilization de barriques en chêne sessile européen (Quercus petraea) ou en chêne blanc américain (Quercus alba) sur la composition et la qualité des vins rouges. Rev. Franç. d'Oenol. 165, 44-48.

Chatonnet, P. \& Dubourdieu, D., 1998. Comparative study of the characteristics of American White Oak (Quercus Alba) and European Oak (Quercus petraea and Q. Robur) for production of barrels used in barrel aging of wines. Am. J. Enol. Vitic. 49, 79-85.

Chatonnet, P., 1999. Discrimination and control of toasting intensity and quality of oak wood barrels. Am. J. Enol. Vitic. 50, 479-494.

Chen, C.L., 1970. Constituents of Quercus alba. Phytochemistry 9, 1149.

Dubourdieu, D., 1992. Elevage des vins blancs en fûts de chêne. In: le bois et la qualité des vins et des eaux de vie. G. Guimberteau (Ed.). Vigne et Vin Publications Internationales, Bordeaux.

Du Penhoat, H.C., Michon, V., Peng, S., Viriot, C., Scalbert, A. \& Gage, D., 1991. Structural elucidation of new dimeric ellagitannins form Quercus robur L. roburins A-E. J. Chem. Soc. Perkin Trans. 1, 1653-1660. 
Feuillat, F., Moio, L., Guichard, E., Marinov, M., Fournier, N. \& Puech, J.L., 1997. Variation in the concentration of ellagitannins and cis- and trans- $\beta$-methyl$\gamma$-octalactone extracted from oak wood (Quercus robur L., Quercus petraea liebl.) under model wine cask conditions. Am. J. Enol. Vitic. 48, 509-515.

Fernandez de Simon, B.F., Cadahia, E., Conde, E. \& Garcia-Vallejo, M.C., 1998. Les ellagitanins dans les bois de chênes espagnols. J. Sci. Tech. Tonnellerie 4, 83-90,

Haslam, E., 1981. Vegetable tannins. In: The biochemistry of plants. Conn E.E. (ed.). Academic Press, New York.

Matricardi, L. \& Waterhouse, A.L., 1999. Influence of toasting technique on color and ellagitannins of oak wood in barrel making. Am. J. Enol. Vitic. 50, 519-526.

Mayer, W., Gabler, W., Riester, A. \& Korger, H., 1967. Die Isolierung von castalagin, vescalagin, castalin und vescalin. Liebigs Ann. Chem. 707, 177-181.

Mayer, V. M., 1971. Uber die gerbstoffe aus dem holz der edelkastanine und eich. Das Leder 1, 1653-1660.

Masson, G., Moutounet, M. \& Puech, J.L., 1994. Localization of the ellagitannins in the tissue of Quercus robur and Quercus petraea woods. Phytochemistry 37, 1245-1249.

Masson, G., Moutounet, M. \& Puech, J.L., 1995. Ellagitannin content of oak wood as a function of species and of sampling position in the tree. Am. J. Enol. Vitic. 46, 262-268.

Mertz, C., 1996. Les tanins du bois de chêne. Diplôme Universitaire en Analyses Chimiques et Physico Chimiques. Université de Montpellier.

Moutounet, M., Rabier, P.H., Puech, J.L., Verette, E. \& Barillere, J.M., 1989. Analysis by HPLC of extractable substances in oak wood. Application to a Chardonnay wine. Sci. Aliments 9, 35-51.

Moutounet, M., Sarni, F. \& Scalbert, A., 1992. Les tanins du bois de chêne; les conditions de leur présence dans les vins. J. Intern. Sci. Vigne vin. $\mathrm{N}^{\circ}$ Hors Série. 75-79.

Moutounet, M., Sarni, F. \& Scalbert, A., 1993. Les tanins du bois de chêne. In: Elevage des vins en fûts de chêne. Y. Glories (Ed.). CEPS, Melun.

Peng, S., Scalbert, A. \& Monties, B., 1991. Insoluble ellagitannins in Castanea sativa and Quercus petraea woods. Phytochemistry 30, 775-778.

Pocock, K.F., Sefton, M.A. \& Williams, P.J., 1994. Taste thresholds of phenolic extract of French and American oak wood: The influence of oak phenols on wine flavor. Am. J. Enol. Vit. 45, 429-434.

Pontallier, P., Salagoity-Auguste, M.H. \& Ribéreau-Gayon, P., 1982. Intervention du bois de chêne dans l'évolution des vins rouges. Connaiss. Vigne Vin. 16, 45-61.

Puech, J.L., 1987. Extraction of phenolic compounds from oak wood in model solution and evolution of aromatic aldehydes in wines aged in oak barrels. Am. J. Enol. Vitic. 38, 236-238.
Puech, J.L., Marinov, M., Labidi, A. \& Robert, A., 1994. Extraction of ellagitannins from oak wood using a flow-through reactor. In: Polyphenols 94. Les Colloques. Ed. INRA. 69, 469-470.

Puech, J.L., Feuillat, F., Mosedale, J.R. \& Puech, C., 1996. Extraction of ellagitannins from oak wood of model casks. Vitis 35, 211-214.

Puech, J.L., Feuillat, F. \& Mosedale, J.R., 1999. The tannins of oak heartwood: Structure, properties, and their influence on wine flavor. Am. J. Enol. Vitic. 50, 469-477.

Puech, J.L., Mertz, C., Michon, V., Herve Du Penhoat, C., Le Guernevec, C. \& Doco, T., 1999. Evolution of castalagin and vescalagin in ethanol. Identification of the new derivates. J. Agric. Food. Chem. 47, 2060-2066.

Quinn, M.K. \& Singleton, V.L., 1985. Isolation and identification of ellagitannins from white oak and an estimation of their roles in wine. Am. J. Enol. Vitic. 36, 429-434.

Scalbert, A., Monties, B. \& Favre, J.-L., 1988. Polyphénols of Quercus robur: adult tree and in vitro growth calli and shoots. Phytochemistry 27, 3483-3488.

Seikel, M.K., Hostettler, F.D. \& Niemann, G.J., 1971. Phenolics of Quercus robur wood. Phytochemistry 10, 2249-2251.

Singleton, V.L., 1995. Maturation of wines and spirits: Comparisons, facts, and hypotheses. Am. J. Enol. Vitic. 46, 98-115.

Viriot, C., Scalbert, A., Lapierre, C.L. \& Moutounet, M., 1993. Ellagitannins and lignins in aging of spirits in oak barrels. J. Agric. Food. Chem. 41, 1872-1879.

Viriot, C., Scalbert, A., Hervé Du Penhoat, C.L. \& Moutounet, M., 1994. Ellagitannins in woods of sessile oak and sweet chestnut dimerization and hydrolysis during wood ageing. Phytochemistry 36, 1253-1260.

Vivas, N. \& Glories, Y., 1993. Les phénoménes dóxydoreduction liès à l'élevage en barrique des vins rouges: Aspects technologiques. Rev. Fr. Oenol. 33, 33-38.

Vivas, N., Laguerre, M., Glories, Y., Bourgeois, G. \& Vitry, C., 1995. Structure simulation of two ellagitannins from Quercus robur L. Phytochemistry 39, 11931199 .

Vivas, N. \& Glories, Y., 1996. Role of oak wood ellagitannins in the oxidation process of red wines during aging. Am. J. Enol. Vitic. 47, 103-107.

Vivas, N., Glories, Y., Bourgeois, G. \& Vitry, C., 1996. The heartwood ellagitannins of different oak (Quercus sp.) and chestnut species (Castenea sativa Mill.). Quantity analysis of red wines aging in barrels. J. Sci. Tech. Tonnellerie 2, 51-75.

Vivas, N., 1997. Recherches sur la qualité du chêne français de tonnellerie (Quercus petraea Liebl. Q. robur L.) et sur les méchanismes d'oxydoréduction des vins rouges au cours de leur élevage en barriques. PhD Thesis, Université de Bordeux II. 